\title{
МЕСТА ПАМЯТИ: ПРОБЛЕМА УВЕКОВЕЧИВАНИЯ УТРАЧЕННЫХ ХРАМОВ (НА ПРИМЕРЕ Г. ПИНСКА)
}

\section{И. Э. ЕЛЕНСКАЯ}

\section{Полесский государственный университет, г. Пинск, Беларусь}

С древних времен место, где проводились религиозные обряды, было особенным, священным, сакральным. Оно противопоставлялось повседневному, требовало от человека особого поведения, чистоты помыслов и возвышенного над обыденностью состояния души. Храм как место для общения с Богом, место молитвы, является для верующих домом Господним, местом приобщения к непознаваемым тайнам Вселенной и смирения перед замыслом Божьим. Вместе с тем, храм - это творение рук человека, созданное усилиями многих людей сооружение, призванное выделиться среди других зданий, гармонично вписаться в окружающий ландшафт, вместить многих верующих и запечатлеть свой образ в памяти людей. Внешний вид храма должен вызывать восхищение и уважение у всех, в том числе у людей других вероисповеданий. Храм - это всегда воплощение достижений в строительстве, архитектуре, искусстве, отражение определенной исторической эпохи, уровня развития культуры.

Многие трагические страницы нашей истории связаны с утратой храмов, принадлежащих разным конфессиям. Сотни церквей, костелов, синагог и мечетей не сохранились. У каждого храма своя собственная уникальная биография, запечатленная в исторических источниках и памяти местных жителей. Существует давняя традиция возведения нового храма на месте утраченного. Например, отстроены заново Благовещенская церковь в Витебске, Спасо-Преображенский кафедральный собор в Слониме, Рождественская церковь в Орше.

Лучший способ не дать исчезнуть памяти о храме и сохранить святость места вернуть храм, дать возможность людям опять приходить сюда с молитвой. И в Пинске дорогу к храму прокладьвают заново.

На берегу у слияния Припяти и Пины находится самое древнее из известных нам на Пиншине сакральных мест. По ичерковным преданиям основателем храма на Лешчнской горке, названного в честь Рождества Пресвятой Богородииь, считается креститель Руси киевский князь Владимир. В исторических источниках под 1263 годом упоминается Лещинский мужской монастырь. В описаниях событий ХІІІ в. отражен факт спасения 8 обители Войшелка - наследника основателя Великого князя Литовского Миндовга. В XIVXV веках Лещинский монастырь был центром православной Турово-Пинской епархии, здесь велось летописание, переписывались переводы богословских трудов. В XVII веке обитель несколько раз переходила от православных к униатам и обратно. В 1840 году монастырь прекратил существование, его территория пришла в запустение. В 1997 году по благословению архиепископа Пинского и Лунинецкого Стефана место, где находился монастырь, обозначили памятным знаком, который освятил митрополит Минский и Слуцкий Филарет. 15 ноября 2011 года здесь прошла закладка камня будущего храма Рождества Пресвятой Богородицы. 31 октября 2020 г. Патриарший экзарх всея Беларуси митрополит Минский и Заславский Вениамин освятил построенный храм Рождества Пресвятой Богородицы на месте древнего Лещинского монастыря [1]. Новый храм не воспроизводит облик прежней церкви, построенной в традициях деревянного зодчества Полесья. Он имеет достаточно необычную для православных храмов круглую форму, напоминающую ротонду.

Многие места в Беларуси, где раньше находились храмы, застроены или пустуют. При этом старожилы точно указывают место, которое ранее занимал храм. Часть утраченных храмов устойчиво ассоциируются с конкретной местностью, значимы для верующих и, не 
существуя физически, продолжают по умолчанию оставаться нашим историко-культурным наследием. Есть такие храмы и в Пинске.

Костел Святого Станислава был построен в г. Пинске в середине XVII в. Храм был возведен за счет пожертвований канцлера ВКЛ, старосты пинского и кобринского Альбрехта Станислава Радзивилла. Размеры костела впечатляли: высота - 28 м, ширина фасада - 25 м, объём кирпичного здания составлял 40 тыс. м ${ }^{3}$, толщина стен превышала 2 м. Массивность храма скрадывали купола и две изящные 11-метровые 3-х ярусные башни-звонницы, устремленные ввысь. Исключительно оригинально был оформлен фасад здания: в его главной части имелись боковые пристройки, завершенные полукружиями стен с арочными проемами. В то время пинский костёл Святого Станислава был самым высоким и вместительным католическим храмом на территории Великого княжества Литовского.

На протяжении трех веков костел Святого Станислава являлся одной из главных архитектурных доминант города. Вместе с возведенным в 1675 г. иезуитским коллегиумом храм составлял единый ансамбль в стиле барокко [1, C. 254]. Расположенные на открытом пространстве рядом с рекой торжественно-величественные сооружения являлись подлинным украшением города, придавая Пинску вместе с архитектурным комплексом монастыря францисканцев, построенным в первой половине XVIII в., неповторимый облик. Путникам город открывался издали с реки и обширных пространств правобережья единой панорамой, очертаниями башен и четко прорисованными силуэтами храмов. В 1773 г. костел Святого Станислава был передан униатской епархии, а в 1795 г. - Русской православной ичеркви. В 1919 г. храм был возвращен иезуитам. В начале Второй мировой войны костел был частично разрушен. В 1953 г. храм по решению городских властей был взорван. Место, где находился костел Святого Станислава, остается незастроенным. Здесь разбит сквер и в дни городских праздников устанавливаются подмостки для выступлений под открытым небом.

Памятно пинчанам еще одно место для молитвы и ритуальных действий - Большая синагога. В XIX - первой половине XX века в Пинске насчитывалось более 40 синагог и молитвенных домов, но каменная синагога, построенная в середине XVII века на средства ремесленного цеха портных, выделялась на общем фоне. Напоминавшая крепость, массивная, внушительная, с двухметровыми по толщине стенами, она стояла в центре города, будто символизируя вечность. В годы Великой Отечественной войньл синагога сильно пострадала, и в 1956 г. была окончательно разобрана [2, С. 388-389]. Позднее на этом месте был построен городской Дом культуры.

Странным образом судьба Большой пинской синагоги созвучна судьбе костела Святого Станислава. Построенные практически в одно время, недалеко друг от друга, эти архитектурные памятники почти синхронно исчезли в ходе послевоенной реконструкции исторического иентра города.

Сохранилось большое количество фотографий костела Святого Станислава, многие из них отличного качества. Храм представлен на снимках 1920-1930-х годов практически со всех сторон и виден полностью - от подножия до вершин крестов. Известны также несколько фотографий Большой пинской синагоги, сделанные с разных ракурсов, что помогает полностью воспроизвести ее облик. Но вопрос о восстановлении этих памятников на сегодняшний день не обсуждается. Это слишком дорогостоящие проекты. Однако поднять проблему сохранения памяти о сооружениях, которые определяли архитектурный облик города, отражали полиэтничность и многоконфессиональность жителей столицы Полесья, очень важно. Намоленные места должны быть обозначены.

В Гродно в 2014 г. открыли памятный знак на месте знаменитого храма Фара Витовта. Он представляет собой скульптурную композицию в виде полуразрушенной арки с памятной надписью. Памятный знак запечатлел сложные моменты нашей общей истории, трагедию разрушения. Его называют Поклонным крестом, он символизирует раскаяние и стремление к единству. Еще одним примером достойного увековечивания памяти об утраченном храме является открытый в 2018 г. в аг. Хомск (Дрогичинский р-н) памятный знак, свидетельствующий о том, что здесь находилась Свято-Покровская церковь, построенная в 
1800 г. и полностью разобранная в 1972 г. Памятный знак представляет собой постамент, на котором стоит большой камень с изображением Свято-Покровской церкви, увенчанный крестом. Рядом расположен старый церковный колокол. И крест, и литой колокол - это сохранившиеся святыни уничтоженного храма.

Опыт последних лет показывает, что мы движемся в правильном направлении, стремясь напомнить людям о прошлом, не позволить забвению одержать победу над исторической памятью. Собор Святого Станислава и Большая синагога в Пинске - это те утраченные объекты, которые заслуживают увековечивания. Следует продумать вопросы о выборе места для памятных знаков. В начале 2019 г. идея поставить на месте, где находился алтарь костела Святого Станислава, памятный знак с моделью храма обсуждалась в социальных сетях [4]. На наш взгляд, надо выступить и с предложением об увековечивании памяти о Большой синагоге. Художественное воплощение образов костела и синагоги должны отвечать таким критериям как уместность и гармоничность. Кроме того, учитывая схожесть в судьбах этих культовых сооружений и близость расположения, представляется обязательным исполнение памятных знаков в одном стиле, возможен вариант создания единой композиции.

Появление памятных знаков в честь утраченных храмов - это путь к возвращению культурного наследия, возрождению истории края, осознанию ошибок, укреплению нравственных и духовных ценностей. А бережно сохраняемая историческая память закладывает основы формирования образа будущего.

\section{Литература}

1. Ильенков, В. Во славу Бога, во благо мира! На Лещинской горке освящен православный храм / В. Ильенков // Пінскі веснік. - 2020. - 3 лістапада. - С. 1-2.

2. Скеп'ян, А. А. Царква і канфесійнае жыццё / А. А. Скап'ян // Гісторыя Пінска. Ад старажытнасці да сучаснасці : да 915-й гадавіны 3 першага летапіснага ўпамінання / А. М. Літвін [і інш.]. - Мінск : Выш. шк., 2012. - С. 233-256.

3. Pinsk // Szlakami Sztetli. Podróże przez zapomniany kontynent / Red. i koordynator projektu Emil Majuk. - Lublin : Brama Grodzka-Teatr NN, 2015. - S. 385-396.

4. В Пинске хотят поставить памятник разрушенному костелу [Электронный ресурс]. Режим доступа : https://planetabelarus.by/publications/v-pinske-khotyat-postavit-pamyatnikrazrushennomu-kostelu-/ - Дата доступа : 02.11.2020.

В статье рассматривается проблема сохранения памяти об утраченных храмах, обоснована необходимость обозначения сакральных мест, содержатся предложения об открытии памятных знаков в память о костеле Святого Станислава и Большой синагоги в г. Пинске.

The article discusses the problem of preserving the memory of the lost churches, substantiates the need to designate sacred places, contains proposals for the opening of memorial signs in memory of the Church of St. Stanislav and the Great Synagogue in Pinsk. 